\title{
PERFORMANCE ENHANCEMENT OF SOLAR STILL BY USING REFLECTORS-JUTE CLOTH-IMPROVED GLASS ANGLE
}

\author{
B.B. Sahoo ${ }^{\text {a,* }}$, and C. Subudhi ${ }^{\mathrm{b}}$ \\ ${ }^{\text {a }}$ School of Mechanical Engineering, Vellore Institute of Technology Vellore, Vellore-632 014, India. \\ ${ }^{\mathrm{b}}$ Department of Mechanical Engineering, Synergy Institute of Engineering and Technology, \\ Dhenkanal-759 001, India.
}

\begin{abstract}
This paper is aimed to improve the productivity of an existing conventional single slope solar still with modifications. In this study, the conventional solar still is modified by using reflectors, jute cloth and improved glass angle. The modified still productivity and performance are investigated experimentally and compared to that of conventional solar still. The results demonstrated that solar still performance is improved with the $10^{\circ}$ glass angle due to better water flow properties and higher solar radiation fall on the still. The results reveal that, with all combined modifications, the water productivity and efficiency of modified solar still increase by $72.18 \%$ and $41.51 \%$ respectively more than the conventional one. This implies that modified solar still could be adopted for higher water productivity at a lower additional cost.
\end{abstract}

Keywords: Solar still; Efficiency; Jute cloth; Glass angle; Reflector; Productivity.

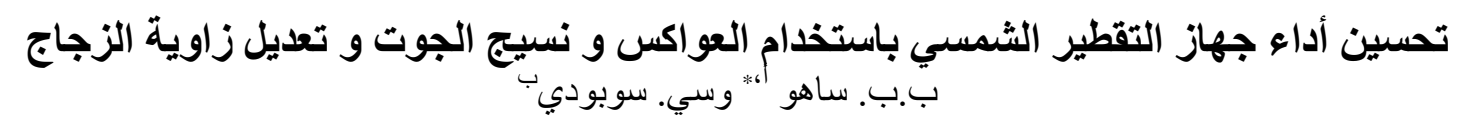

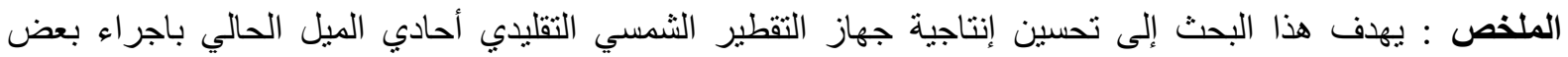

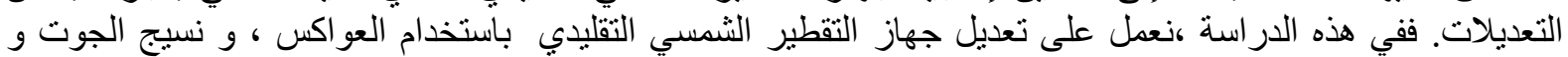

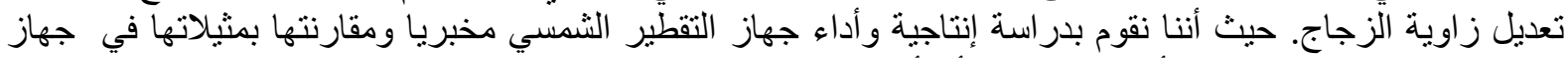

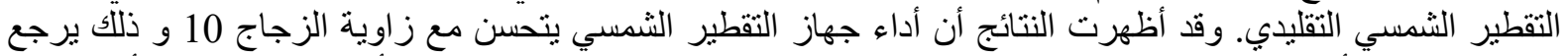

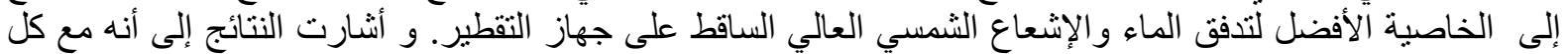

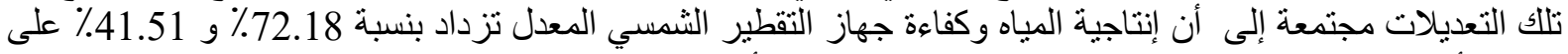
التوالي أكثر من مثيلاتها في جهاز التقطير التقليدي. وهذا يعني أنه يمكن تنني جهاز التقطير الثمسي التيان المعدل لزيادة إنتاجية المياه بتكلفة إضافية أقل.

الكلمات المفتاحية : جهاز التقطير الثمسي ؛ الكفاءة ؛ نسيج الجوت ؛ زاوية زجاجية ؛ العاكس ؛ الإنتاجية.

Corresponding author’s e-mail: bbs.iitg@gmail.com

DOI: 10.24200/tjer.voll6iss1pp1-10 


\section{NOTATIONS}

$\begin{array}{ll}\mathrm{A}_{\mathrm{g}} & \text { Area of the glass plate }\left(\mathrm{m}^{2}\right) \\ \mathrm{cm} & \text { Centimeter } \\ \mathrm{E} & \text { East } \\ \text { lts } & \text { Litere } \\ \mathrm{Ml} & \text { Millilitre } \\ \mathrm{N} & \text { North } \\ \mathrm{Q} s & \text { Solar radiation }\left(\mathrm{W} / \mathrm{m}^{2}\right) \\ \mathrm{T}_{\mathrm{wi}} & \text { Water inlet temperature }\left({ }^{\circ} \mathrm{C}\right) \\ { }_{\mathrm{o}} & \text { Degree } \\ \lambda & \text { Transmissivity } \\ \mathrm{CFD} & \text { Computational fluid dynamics } \\ \mathrm{CSS} & \text { Conventional solar still } \\ \mathrm{h}_{\mathrm{fg}} & \text { latent heat of water vapour }(\mathrm{J} / \mathrm{kg}) \\ \mathrm{MCSS} & \text { Modified conventional solar still } \\ \mathrm{m}_{\mathrm{v}} & \text { Mass of distillate output }(\mathrm{kg} / \mathrm{s}) \\ \mathrm{Q}_{\mathrm{in}} & \text { Solar input }(\mathrm{W}) \\ \mathrm{T} & \text { Temperature }\left({ }^{\circ} \mathrm{C}\right) \\ \mathrm{W} & \text { Watt } \\ { }^{\circ} \mathrm{C} & \text { Degree centigrade } \\ \eta_{\mathrm{st}} & \text { Solar still efficiency }(\%)\end{array}$

\section{INTRODUCTION}

The shortage of clean, drinking water because of global warming, climate change and population growth is a concern for the world today. Therefore, the challenge for both developing and developed countries is to provide good quality drinking water. Of the total water available on the earth, about $97.5 \%$ contains salt and harmful bacteria that cannot be directly used for healthy drinking purpose Kumar et al. (2015). Hence, we need a technology which can produce purified drinking water by distilling brackish and saline water. An efficient, cheap and environment friendly technique to supply clean and safe drinking water is the 'solar still'. It is a solar energy system technology that is capable of removing a very wide variety of contaminants from water in just one step distillation process Bhattacharyya (2013).

The solar still is a simple, inexpensive and efficient system. The equipment primarily consists of a shallow basin with a transparent glass or plastic cover. When the radiation heat from the sun falls inside the glass covered chamber, the basin water is heated. Then the higher sun temperature evaporates the heated water in the basin. Moisture rises and the water vapour condenses when it reaches the cool glass or plastic cover. The water droplets run down into a collection trough to give salts, minerals, germs and impurities free pure water Sahoo et al. (2008).

In the past, several attempts were made by many researchers to increase water productivity and utilize the maximum solar radiation on the still to increase the system efficiency. Iranean scientists Rahbar and Esfahani have shown splendid interest in the solar still research in all respects; theoretical, numerical and experimental. The researchers developed a new correlation for estimating the convective heat transfer coefficient which showed good agreement with the published well-known models Rahbar and Esfahani (2012-2). The same researchers improved the solar still productivity at different operating conditions by using CFD simulation work (Rahbar and Esfahani 2013; Rahbar et al. 2015). The authors and their colleagues carried out extensive experimental work to improve the performance of various types of solar still. Utilizing a heat pipe and thermoelectric module to a solar still, the authors improved the productivity (Rahbar and Esfahani 2012-1; Rahbar et al. 2016). It was due to the reduction in the start of distillation point with a thermoelectric cooler. The productivity of the solar still can be enhanced by adopting different techniques like partitioning of solar still Rashidi et al. (2016) and the use of porous media Rashidi et al. (2018-1) and nano fluid Rashidi et al. (2018-2) in a solar still. The same researchers also performed energy and cost analysis of the modified solar stills (Rashidi et al. 2017; Rashidi et al. 2018-a). The cost of water from the modified stills were found to be much less than the conventional solar still.

The glass inclination angle is a design parameter of the solar still that influences the productivity from a solar still Kaviti et al. (2016). The increase in the still inclination produces a higher surface area and a thin water surface. Hence, the still productivity increased for a higher glass inclination angle Murugavel et al. (2013). In an experimental work, five different glass cover inclination solar stills tilted at different angles from $15^{\circ}$ to $45^{\circ}$ were studied. The results showed that $15^{\circ}$ glass cover inclination system was the best among the five models Hashim et al. (2010). In another work on a single basin solar still, two glass inclination combinations, $30^{\circ}$ and $23^{\circ}$, were tested. The $30^{\circ}$ inclination of the solar still was found to be more efficient Dinesh et al. (2013). The effect of glass inclination angle was investigated in two previous investigations with covering glass angles of $4^{\circ}, 7^{\circ}, 10^{\circ}$, $13^{\circ}, 15^{\circ}, 30^{\circ}$ and $45^{\circ}$ respectively (Edioja et al. 2013; Singh et al. 2013). Ten solar stills with different glass inclination angles, 10-55 in steps of $5^{\circ}$ were experimented for still performance. The results demonstrated that the angles $20^{\circ}$ and $25^{\circ}$ provide the optimum still performance Azooza and Younis (2016).

The inclusion of reflectors, either externally or internally, to a solar still increases the solar irradiation to basin water and it raises the still efficiency Omara et al. (2017). To enhance the performance of solar stills, the use of internal reflectors were tried by the scientists (Abdallah et al. 2008; Tankaka, 2009; Omara et al. 2016). The water temperature of solar still was increased due to addition of solar reflection into basin water. In 2016, Omara et al. (2014) presented two solar still modifications using a double layer wick material and internal reflectors. They found $145.5 \%$ higher productivity for the modified stills as compared to the conventional solar still Omara et al. (2014). 
Increasing the basin water surface area, water temperature increases and hence, increases in the evaporation rate from the top layer of the water. This caused an increase in water productivity from solar still (Manokar et al. 2014; Samuel et al. 2016). This concept was tried by placing sponge cubes over the water surface of the solar still and it caused an increase of yield by $18 \%$ Bassam et al. (2003). Few researchers have conducted experiments on this concept on solar still by using jute cloths or wick at different positions, horizontal, vertical and on the water surface (Shukla and Sorayan 2005; Bouchekima et al. 1998; Sakthivel et al. 2010; Mona et al. 2002). With all positions of jute cloth, the modified solar still yield and efficiency improved due to an increase in surface area and rate of evaporation. In some other experimental works, the absorption materials like black rubber mat, charcoals, black dye, black gravel and black ink were tried to enhance the still efficiency (Mona et al. 2002; Nafey et al. 2001; Bilal et al. 1998). The still yield increased from $35 \%$ to $60 \%$ with charcoal and wick combined modifications.

From the above literature survey, it is found that "solar still" is one of the very important equipment for producing drinking water. Also, several researchers demonstrated the enhancement of simple solar still productivity and efficiency with appropriate modifications in the design of glass cover and basin. With this in mind, in the present work, various combinations of solar still performance enhancement techniques are presented. Then, these combinations are investigated experimentally to find out water productivity rate and efficiency from the modified solar still.

\section{WORK OBJECTIVE}

Previous studies have attempted various modifications to improve the productivity of solar stills. The objective of the present work is to conduct experimental investigations on three combined modifications on a conventional single slope solar still. The modifications done here to the original solar still are: (i) changes in glass inclination angle; (ii) fixing reflectors to both sides of still; and (iii) placing jute cloth horizontally on the basin water. In this communication, three modified still combinations were examined experimentally and discussed with respect to the system performance.

\section{THEORETICAL ASPECT}

\subsection{Solar Input Measurement}

In this work, energy input to the solar still was from sun only. Transmissivity $(\lambda)$ of the glass was determined by measuring the ratio of solar intensity over and under the glass. The average value of $\lambda$ was calculated as 0.847 and it was approximated to 0.85 for calculation purpose. The area of glass plate was assumed equal to the area of the solar still in the calculation of solar input to the still. Solar input $\left(Q_{i n}\right)$ to the still was evaluated by multiplying the solar radiation by the transmissivity of the glass cover is presented in Equation (1) Tiwari et al. (2009).

$Q_{\text {in }}=\tau A_{g} Q_{s}, W$

where $\lambda=$ transmissivity of the glass $(=0.85)$,

$\mathrm{A}_{\mathrm{g}}=$ area of the glass plate $(1.10 \mathrm{~m} \times 1.10$ $\mathrm{m}=1.21 \mathrm{~m}^{2}$ ), and

$Q_{\mathrm{s}}=$ solar radiation $\left[\mathrm{W} / \mathrm{m}^{2}\right]$.

Solar radiation $\left(\mathrm{Q}_{\mathrm{s}}\right)$ was measured hourly by a 'lux meter' during the solar still testing period of the day. Its average value of the total testing hours was considered for the solar input calculation. The lux unit reading of the instrument was converted into the unit of $\mathrm{W} / \mathrm{m}^{2}$ by multiplying by a conversion factor of 0.0161028 . The specifications of Testo make lux meter are presented in Table 1.

Table 1. Specifications of Lux Meter.

\begin{tabular}{lll}
$\begin{array}{l}\text { Sl. } \\
\text { No. }\end{array}$ & $\begin{array}{l}\text { Name of the } \\
\text { Instrument }\end{array}$ & \multicolumn{1}{c}{$\begin{array}{c}\text { Specification of the } \\
\text { Instrument }\end{array}$} \\
\hline 1 & Lux meter & $\begin{array}{l}\text { Make: Testo }-540 \\
\text { Measuring range: } 0 \text { to } \\
\text { 99999 Lux } \\
\end{array}$ \\
& Accuracy: \pm 3 Lux or $\pm 3 \%$ \\
& Resolution: 1 Lux (0 to \\
& 19999 Lux) \\
& 10 Lux (Remaining Range) \\
& & Measuring rate: 0.5 second \\
\hline
\end{tabular}

\subsection{Still Efficiency Calculation}

It is the ratio of the heat energy utilized for water evaporation to the total solar radiation energy received by the still Tiwari et al. (2009). It was assumed that a small amount of sensible energy consumed by distillate water is compared to its latent heat and hence, it was neglected in the still efficiency calculation. Due to the glass small angle, it was assumed that the amount of solar radiation on the solar still to slope of glass is unaffected.

$\eta_{s t}=\left\lfloor m_{v} \times h_{f g}\right\rfloor \div\left\lfloor\lambda A_{g} Q_{s}\right\rfloor$

where $\mathrm{m}_{\mathrm{v}}=$ mass of distillate output $(\mathrm{kg} / \mathrm{s})$,

$\mathrm{h}_{\mathrm{fg}}=$ latent heat of water vapor $\left(=2257 \times 10^{3}\right.$ $\mathrm{J} / \mathrm{kg}$.

\subsection{Measurement of Distillate Output}

The hourly collected still distillate output was collected and measured in a scaled measuring glass jar on volume basis. This volumetric distillate output was then converted into mass basis and is taken as $\mathrm{m}_{\mathrm{v}}$ in $\mathrm{kg} / \mathrm{s}$ for calculation purpose. 


\subsection{Measurement of Temperature}

The temperature was recorded during the tests with the help of alcohol in-glass thermometer of 0 $100{ }^{\circ} \mathrm{C}$ range at three different places, water, outside glass and ambient temperature.

\section{EXPERIMENTAL INVESTIGATION}

The tested experimental setup is installed at the Mechanical Department, Synergy Institute of Engineering and Technology, Dhenkanal, India. The schematic diagram of the single slope solar still setup is shown in Fig. 1. The black painted still basin is made from $3 \mathrm{~mm}$ thick fibre-reinforced plastic with a maximum of 25 litres water capacity. The top of the still is covered by $6 \mathrm{~mm}$ thick and $1.10 \mathrm{~m} \times 1.10 \mathrm{~m}$ area glass and placed at $8^{\circ}$ inclination to the horizontal. The leakage of heat and water vapour from the solar still are prevented by filling putty between the glass cover and side edges of still space.

\subsection{Test Matrix}

One set of baseline tests was carried out on the existing conventional solar still. The still was modified with the following alteration by: (i) increasing glass inclination angle to $10^{\circ}$ for better water flow conditions; (ii) fixing $20 \mathrm{~cm}$ height reflectors at $60^{\circ}$ angle to both sides of still top layer to increase solar radiation on water Maambo and Simate (2016); (iii) placing jute cloth horizontally on the basin water to increase evaporation surface area. These three sets of experimentations were conducted on the modified conventional still. The complete particulars on the test matrix adopted for the experiments on solar still are presented in Table 2.

The schematic diagrams of the modified solar still operations setup of MCSS-2 and MCSS-3 the modes are presented in Fig. 2 and Fig. 3 respectively.

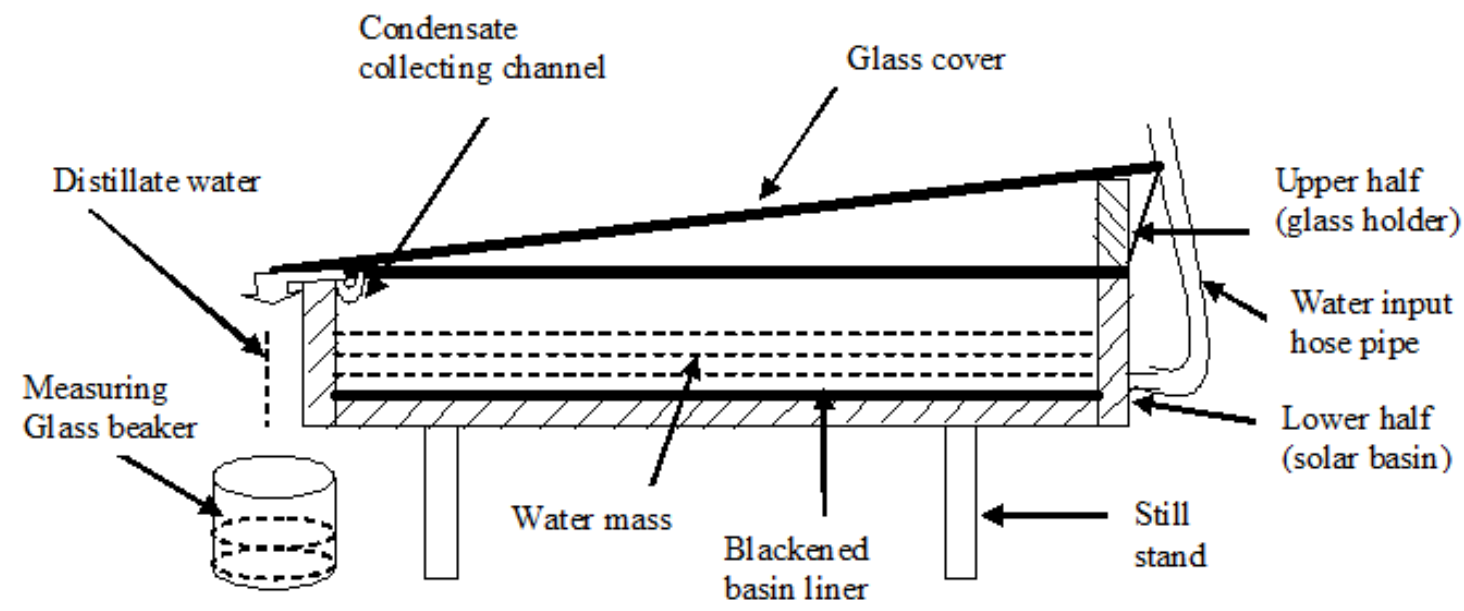

Figure 1. Schematic Diagram of Conventional Solar Still (CSS).

Table 2. Test Matrix.

\begin{tabular}{llc}
\hline $\begin{array}{c}\text { Designation } \\
\text { of } \\
\text { Operation }\end{array}$ & \multicolumn{1}{c}{ Features of Solar Still } & $\begin{array}{c}\text { Quantity of } \\
\text { Water (lts) }\end{array}$ \\
\hline CSS & Conventional solar still $\left(8^{\circ}\right.$ inclination) & 15 \\
MCSS-1 & Modified Conventional solar still $-10^{\circ}$ inclination & 15 \\
MCSS-2 & $\begin{array}{l}\text { Modified Conventional solar still }-10^{\circ} \text { inclination, reflector fixed at } 60^{\circ} \\
\text { angle to both sides of the still }\end{array}$ & 15 \\
MCSS-3 & $\begin{array}{l}\text { Modified Conventional solar still }-10^{\circ} \text { inclination, reflector fixed at } 60^{\circ} \\
\text { angle to both sides of the still, placing Jute cloth on the basin water }\end{array}$ & 15 \\
\hline
\end{tabular}




\subsection{Experimental Procedure}

To the test matrix, all tests were carried out in the Dhenkanal district of Odisha state with geographical coordinates of $20.8424^{\circ} \mathrm{N}, 85.4376^{\circ} \mathrm{E}$, India. The experiments were carried out on the south faced solar still from 10 AM to 03 PM during February - March, 2017. The amount of water was kept as 15 liters in the still basin during the experimentation. The amount of water was fed into the still by the fabricated hose pipe arrangement. The initial temperature of water and atmosphere were recorded. The basin water received the solar radiation, got heated and evaporated. The water vaporized and condensed against the glass cover. The glass temperature and solar radiation were recorded at hourly interval basis. The water molecules slide down through the glass inclination to the collecting channel and fell on collected measuring jar. The hourly distillate from the solar still was collected and measured. Three sets of experiments were conducted for each test matrix and the average observed parameters were used for performance analysis of the solar still. The same experimental procedures were followed to evaluate the modified sill performances as per the test matrix and the average recorded parameters were considered for analysis purpose.

\subsection{Measurement Errors}

$N_{s t}=f\left(m_{v}, A_{g}, Q_{s}, T_{w i}\right)$

The uncertainties associated with the calculation of solar still efficiency were estimated by using sequential perturbation techniques Kline and McClintock (1953). It included contributions from uncertainties in measurement volume of collected distillate $(1 \%)$, initial water temperature $(0.5 \%)$, area of the glass plate $(0.1 \%)$ and solar radiation $(0.1 \%)$. Based on the above values, the still efficiency was believed to be accurate within $\pm 2 \%$.

\section{RESULTS AND DISCUSSION}

The various temperatures, solar radiation and distillate output were measured on hour intervals on the day of experimentation on the solar still with 15 liters water capacity. The results were analyzed and compared for both the modified and the conventional solar stills as per defined test matrix.

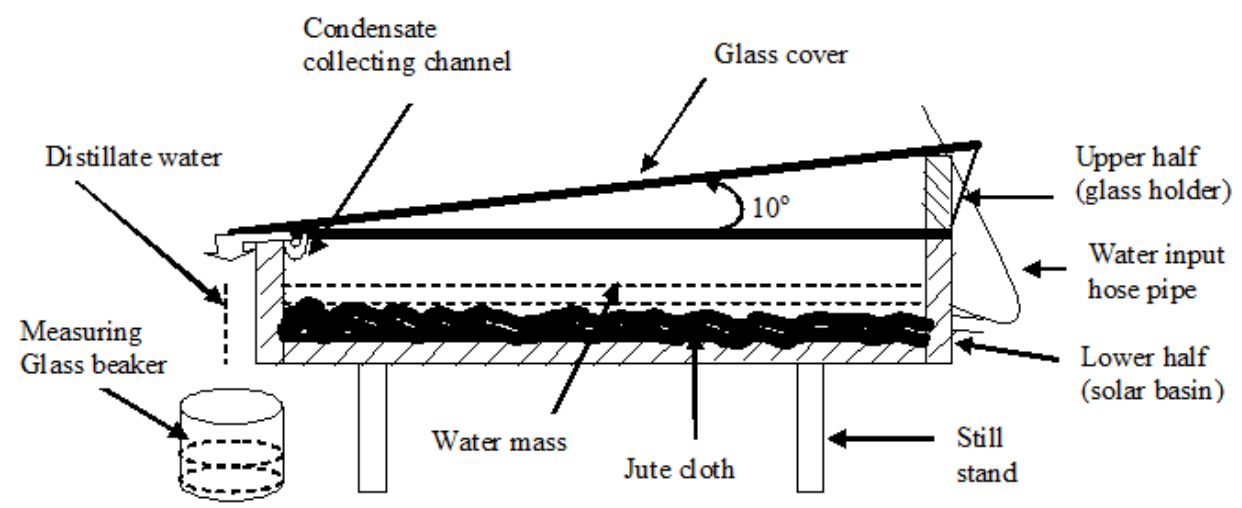

Figure 2. Schematic Diagram of Modified Solar Still (MCSS-2).

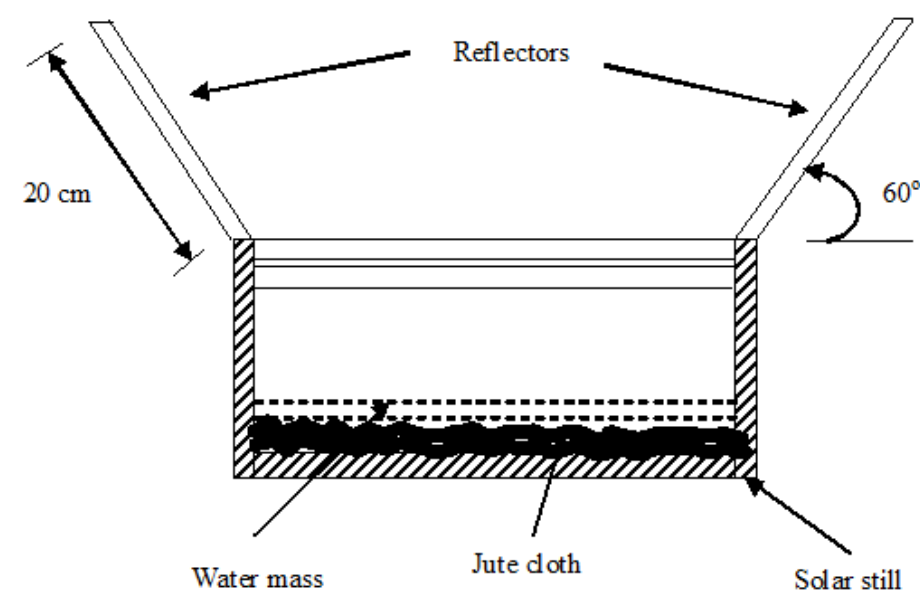

Figure 3. Schematic Diagram of Modified Solar Still (MCSS-3). 


\subsection{Solar Radiation}

The solar radiation is increased gradually from morning hours as the day progresses, as shown in Fig. 4. For all modes of still operation, its highest value is reached at 12 noon and then decreases until $3 \mathrm{pm}$. The solar intensity values are varied from $583 \times 10^{3}$ to $1000 \times 10^{3}$ lux units during the experimentation.

\subsection{Ambient Temperature}

Figure 5 shows that the ambient temperatures are varied from $27{ }^{\circ} \mathrm{C}$ to $41{ }^{\circ} \mathrm{C}$ in the days of still operation. For all the modes, the highest value of ambient temperature is obtained at $1 \mathrm{PM}$ of the day.

\subsection{Glass Temperature}

In general, the solar radiation on the earth begins to increase from morning hours, reaches to maximum values around mid-day and then decreases in the afternoon. Due to this solar intensity variation, it is observed that the glass temperatures for all modes go up as the day progresses and reaches a maximum value at $2 \mathrm{pm}$ for all the operation days (Fig. 6). The MCSS-3 mode of operation produced highest glass temperature of $50{ }^{\circ} \mathrm{C}$ followed by MCSS-2 $\left(49{ }^{\circ} \mathrm{C}\right)$, MCSS-1 $\left(44{ }^{\circ} \mathrm{C}\right)$ and CSS $\left(44^{\circ} \mathrm{C}\right)$. The increase in solar energy absorption due to reflectors with MCSS2 and MCCS-3 modes increase the glass temperatures. The increase in solar radiation increases the evaporation and condensation of the basin water. So, the glass temperatures in both MCSS-2 and MCCS-3 modes are higher compared to CSS and MCCS-1 modes. In MCSS-3 mode, the increase in surface area due to jute cloth absorbs more heat energy and hence, it showed the highest glass temperature. The maximum glass temperatures are recorded equal with CSS and MCSSS-1 modes. However, the difference in maximum and minimum glass temperatures of MCSS1 mode is found higher than that of CSS mode. To achieve maximum glass temperature and best performance from the still, the glass angle should be increased further up to the place latitude angle of $20.8424^{\circ}$.

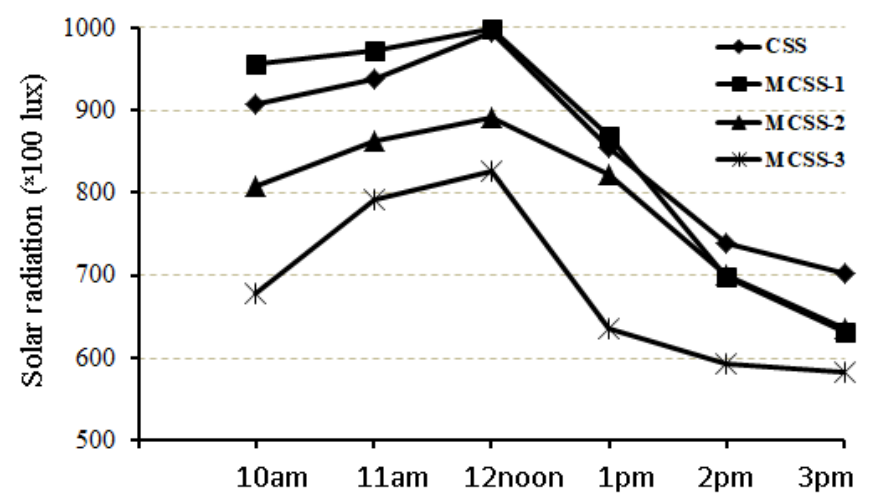

Figure 4. Variation of solar radiation on the days of operation.

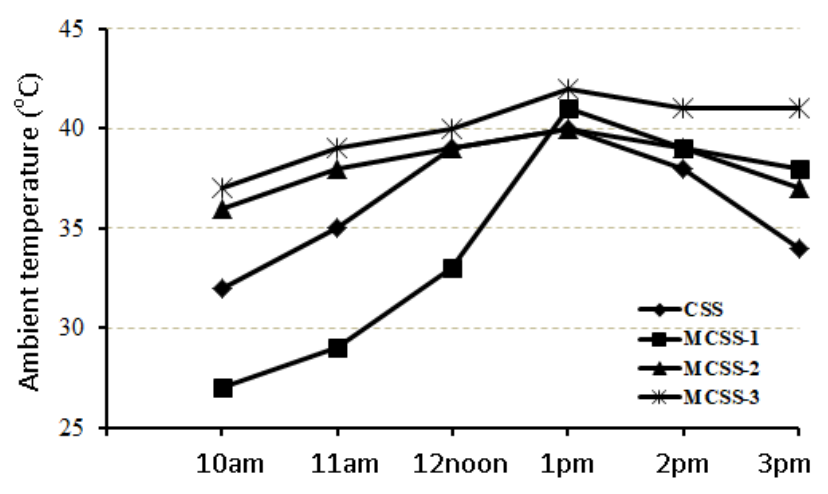

Figure 5. Variation of ambient temperature on the days of operation. 


\subsection{Distillate Output}

The hourly distillate output variation with the day progress is shown in Fig. 7. It is observed that the distillate output began at nil in the morning at $10 \mathrm{am}$, increased and till 2:00 pm of the day. After $2 \mathrm{pm}$, the water productivity of CSS and MCSS- 1 modes are reduced. But, MCSS-2 and MCSS-3 modes showed enough water production potential even after 2:00 pm. In general, the distilled water productivity of the still varies proportionally to solar radiation and ambient temperature. Due to more solar absorption capability, more water yield is found with MCSS-2 and MCSS-3 modes modified solar stills. The maximum distillate output is recorded $189 \mathrm{ml}$ and $181 \mathrm{ml}$ per hour from MCSS-2 and MCSS-3 modes respectively around 3:00 PM.

The ability of higher evaporation and condensation rates of the modified stills (MCSS-2 and MCSS-3) produced more water yield than CSS and MCSS-1 modes of operation. This is the same reason that generates more glass temperatures. So, the daily water production from the MCSS-2 $(707 \mathrm{ml})$ and MCSS-3 $(718 \mathrm{ml})$ are found more than that of the other modes CSS (417 ml) and MCSS-1 (664 ml) as shown in Fig. 8. The water yield output of MCSS-1 and MCSS-2 are increased by $59.23 \%$ and $69.54 \%$ respectively compared with the CSS mode. The distillate water yield in the MCSS-3 mode is increased by $72.18 \%$ as compared to the CSS mode. This is due to the combined modifications effect of $10^{\circ}$ glass inclination, reflectors and jute cloth operation of MCSS-3 mode which produced increased solar radiation absorption, higher evaporation and condensation water rate.

\subsection{Still Efficiency}

Figure 9 shows the comparison of efficiency for all four modes of operations solar still. The still efficiencies are found to be $10.6 \%, 12.31 \%, 13.6 \%$ and $15 \%$ for the modes CSS, MCSS-1, MCSS-2 and MCSS-3 respectively. The MCSS-3 mode operation of solar still showed $42.31 \%$ higher efficiency than that of the original CSS mode. The increase in the glass inclination to $10^{\circ}$ provided better water flow slope and also improved solar radiation fall on basin water as compared to the original $8^{\circ}$ inclination. The amount of solar radiation on water is increased due to reflectors. Jute cloth inside the basin increased the water evaporation surface area. Combining the benefits all together, the water productivity and, hence, the still efficiency is increased by a huge margin of $42.31 \%$ for MCSS-3 mode as compared to the original CSS setup.

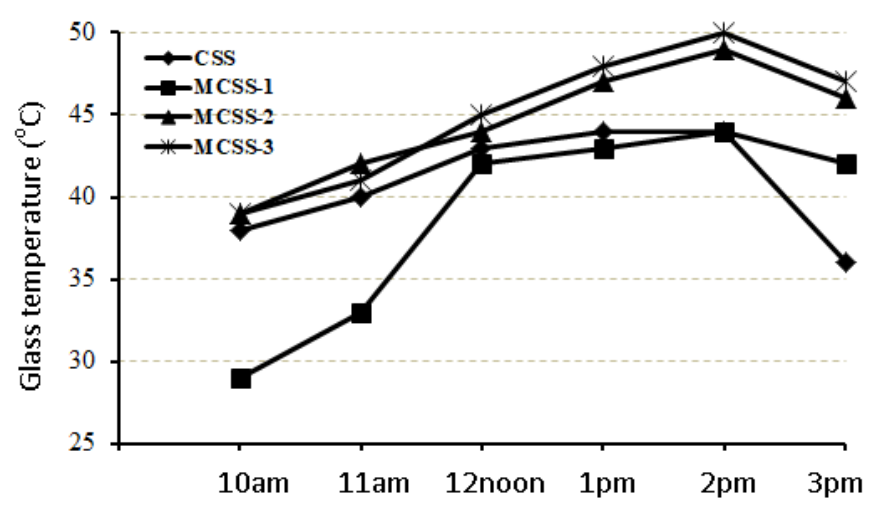

Figure 6. Variation of glass temperature on the days of operation.

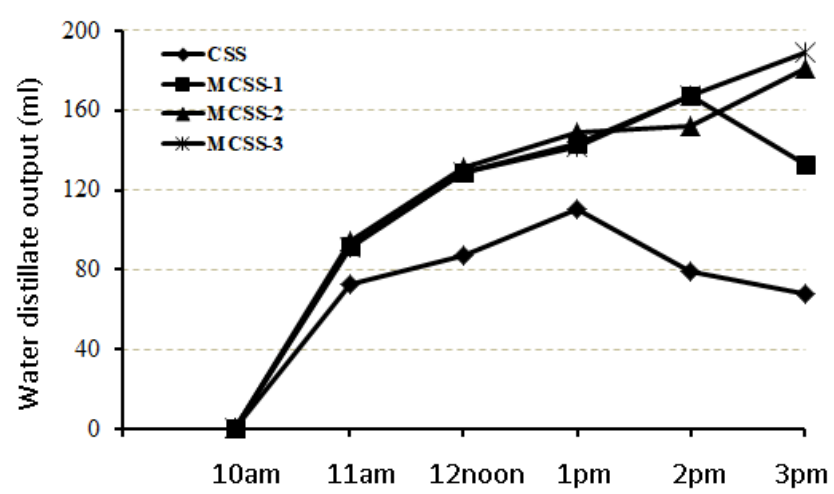

Figure 7. Variation of hourly distillate water output on the days of operation. 


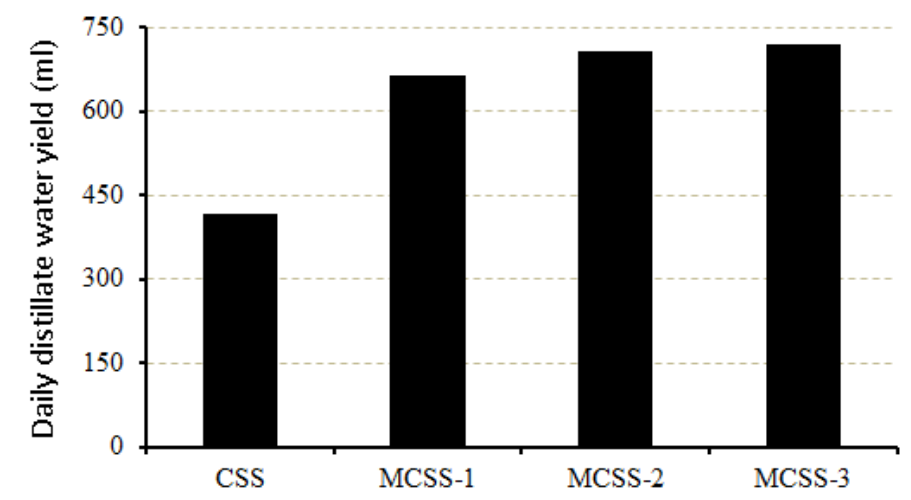

Figure 8. Average distillate water output for all modes operation.

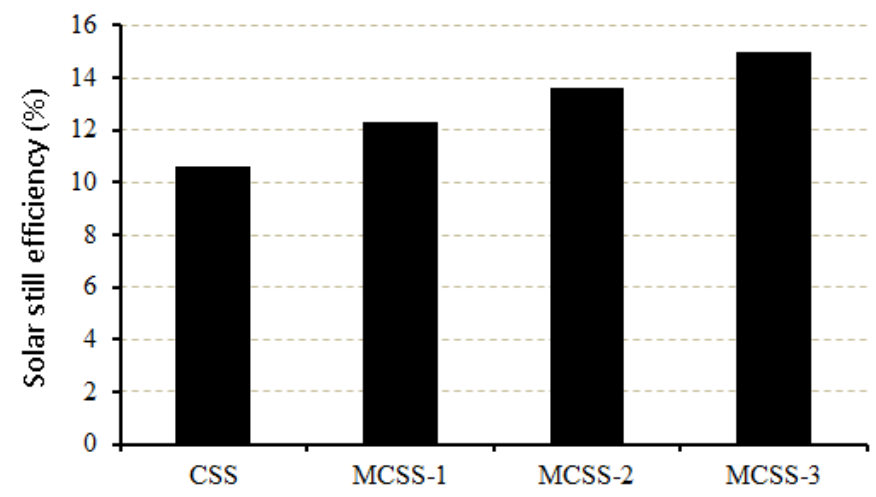

Figure 9. Variation of solar still efficiency for all modes of operation.

Table 3. Comparison of Water Productivity of Different Single Slope Solar Stills.

\begin{tabular}{lc}
\hline \multicolumn{1}{c}{ Still Specifications } & $\begin{array}{c}\text { Increase in } \\
\text { Productivity }\end{array}$ \\
\hline Still with asphalt and sprinkler [Badran, 2007] & $51 \%$ \\
Still with internal mirrors and step-wise basin [Abdallah et al. 2008] & $180 \%$ \\
Stepped solar still with internal reflectors [Omara et al. 2013] & $75 \%$ \\
Still with fins at bottom [Velmurugan et al. 2008] & $45.5 \%$ \\
Still with water coral fleece with stepped wire mesh absorber [Hansen et al. & $71.2 \%$ \\
2015] & 72.18 \\
Present work (Still with increased glass angle, jute cloth and reflectors) & \\
\hline
\end{tabular}

\subsection{Comparison of Productivity of Different Single Slope Solar Stills}

The comparison of water productivity of previous Researchers' works and present work is represented in Table 3.

\section{CONCLUSION}

This study deals with the performance enhancement of a conventional solar still by using low cost modifications such as reflectors, jute cloth and improved glass angle. The collected data during the experimentation days were analyzed and the findings were summarized below.

- The modified solar still with $10^{\circ}$ inclination angle in MCSS-1 mode produces better water angular flow water properties with $16.31 \%$ more still efficiency than that of the original CSS mode. Also, the water productivity of MCSS-1 mode moves up by $59.23 \%$ as compared to CSS mode.

- By fixing reflectors on the sides of the still (MCSS-2 mode), the water productivity and still efficiency increases by $69.54 \%$ and $28.3 \%$ respectively as compared with the CSS 
operation. Water production increases by 290 ml with MCSS-2 mode for the solar still hours of operation as compared to that of CSS mode.

- The MCSS-3 mode produces a maximum glass temperature of $50^{\circ} \mathrm{C}$ when solar radiation absorbing capacity of the still is increased by using jute cloth to the basin water area along with reflectors and improved glass angle.

- Water productivity of the MCSS-3 mode is $718 \mathrm{ml}$ on the day of operation which is an enhancement amount of $72.18 \%$ over CSS mode.

- $\quad$ The MCSS-3 mode produces $41.5 \%$ higher still efficiency with all combined modifications as compared to that of $10 \%$ efficient CSS mode.

\section{CONFLICT OF INTEREST}

The authors declare no conflicts of interest.

\section{FUNDING}

No funding was received for this research.

\section{ACKNOWLEDGMENT}

The authors wish to thank and acknowledge their B.Tech and M.Tech students, Vellore Institute of Technology, for their assistance towards experimenttation and data collection for the entire experiment days.

\section{REFERENCES}

Abdallah S, Badran O, Abu-Khader MM (2008), Performance evaluation of a modified design of a single slope solar still. Desalination 219: 222-230.

Abu-HijlehBassam AK, Rababa'h HM (2003), Experimental study of solar still with sponge cubes in basin. Energy Conversion Management 44: 1411-1418.

Akash A, Mohsen MS, Omar O, YaserElayan (1998), Experimental evaluation of a single-basin solar still using different absorbing materials. Renewable Energy 14: 307-310.

Amitava B (2013), Solar stills for desalination of water in rural households. International Journal of Environment and Sustainability 2(1): 21-30.

Azooza A, Younis GG (2016), Effect of glass inclination angle on solar still performance. Journal of Renewable and Sustainable Energy 8(3): 033702-1-033702-12.

Badran O.O. (2007), Experimental study of the enhancement parameters on a single slope solar still productivity. Desalination 209: 136-143.

Bouchekima B, Gros B, Ouahes R, Diboun M (1998), Performance study of the capillary film solar distiller. Desalination 116: 185-192.

Dinesh K, Himanshu P, Zameer A (2013), Performance analysis of single slope solar still. International Journal of Emerging Technology and Advanced Engineering 3(3): 66-72.

Edeoja O, Unom F, Edeoja JA (2013), Investigation of the effect of angle of cover inclination on the yield of a single basin solar still under Makurdi climate. International Journal of Engineering Science 2(7): 131-138.

Hansen RS, Narayanan CS, Murugavel KK (2015), Performance analysis on inclined solar still with different new wick materials and wire mesh. Desalination 358: 1-8.

Hashim AY, Al Asadi MJ, TahaAlramdhan WA (2010), An attempt to solar still productivity optimization; solar still shape, glass cover inclination and inner surface area of a single basin solar still, optimization. Basrah Journal of Science 28(1): 39-48.

Kaviti AK, Yadav A, Shukla A (2016), Inclined solar still designs: A review. Renewable and Sustainable Energy Reviews 54: 429-451.

Kline SJ, McClintock F.A. (1953), Describing uncertainties in single-sample experiments. Mechanical Engineering 75: 3-8.

Kumar PV, Kumar A, Prakash O, Kaviti AK (2015), Solar stills system design: a review. Renewable and Sustainable Energy Review 51: 153-181.

Maambo H, Simate I (2016), Performance improvement of solar water stills by using reflectors. Journal of Humanitarian Engineering 4(2): 8-15.

Manokar A.M, Murugavel K.K, Esakkimuthu $\mathrm{G}(2014)$, Different parameters affecting the rate of evaporation and condensation on passive solar stillA review. Renewable and Sustainable Energy Reviews 38: 309-322.

Murugavel K.K, Anburaj P, Samuel R.H, Elango T (2013), Progresses in inclined type solar stills. Renewable and Sustainable Energy Reviews 20: 364-377.

Naim M.M, AbdEI Kawi M.A (2002), Nonconventional solar stills part-1 nonconventional solar stills with charcoal particles as absorber medium. Desalination 153: 55-64.

Nafey A.S, Abdelkader M, Abdelmotalip A, Mabrouk A.A (2001), Solar still productivity enhancement. Energy Conversion Management 42: 1401-1408.

Omara Z.M, Kabeel A.E, Younes M.M (2013), Enhancing the stepped solar still performance using internal reflectors. Desalination 314: 67-72.

Omara Z.M, Kabeel A.E, Younes M.M (2014), Enhancing the stepped solar still performance using internal and external reflectors. Energy Conversion Management 78: 876-881. 
Omara Z.M, Kabeel A.E, Abdullah A.S, Essa F.A (2016), Experimental investigation of corrugated absorber solar still with wick and reflectors. Desalination 381: 111-116.

Omara Z.M, Kabeel A.E, Abdullah A.S (2017), A review of solar still performance with reflectors. Renewable and Sustainable Energy Reviews 68: 638-649.

Rahbar N, Esfahani J.A (2012-1), Experimental study of a novel portable solar still by utilizing the heatpipe and thermoelectric module. Desalination 284: 55-61.

Rahbar N, Esfahani J.A (2012-2), Estimation of convective heat transfer coefficient in a single-slope solar still: a numerical study. Desalination and Water Treatment 50: 387-396.

Rahbar N, Esfahani J.A (2013), Productivity estimation of a single-slope solar still: Theoretical and numerical analysis. Energy 49: 289-297.

Rahbar N, Esfahani J.A, Fotouhi-Bafghi E (2015), Estimation of convective heat transfer coefficient and water-productivity in a tubular solar still - CFD simulation and theoretical analysis. Solar Energy 113: 313-323.

Rahbar N, Esfahani J.A, Asadi A (2017), An experimental investigation on productivity and performance of a new improved design portable asymmetrical solar still utilizing thermoelectric modules. Energy Conversion and Management 118: 55-62.

Rashidi S, Bovand M, Esfahani J.A (2016), Optimization of partitioning inside a single slope solar still for performance improvement. Desalination 395: 79-91.

Rashidi S, Esfahani J.A, Rahbar N (2017), Partitioning of solar still for performance recovery: Experimental and numerical investigations with cost analysis. Solar Energy 153: 41-50.

Rashidi S, Rahbar N, Valipour M.S, Esfahani J.A (2018-1), Enhancement of solar still by reticular porous media: Experimental investigation with exergy and economic analysis. Applied Thermal Engineering 130: 1341-1348.
Rashidi S, Bovand M, Rahbar N, JavadAbolfazliEsfahani J.A (2018-2), Steps optimization and productivity enhancement in a nanofluid cascade solar still. Renewable Energy 118: 536-545.

Sakthivel M, Shanmugasundaram S, Alwarsamy T (2010), An experimental study on a regenerative solar still with energy storage medium - Jute cloth. Desalination 264: 24-31.

Sahoo B.B, Sahoo N, Mahanta P, BorboraL, Kalita P, Saha U.K (2008), Performance assessment of a solar still using blackened surface and thermocol insulation. Renewable Energy 33: 1703-1708.

Samuel D.G.H, Nagarajan P.K, Arunkumar T, Kannan E, Sathyamurthy R (2016), Enhancing the solar still yield by increasing the surface area of water-A review. Environmental Progress and Sustainable Energy 35(3): 815-822.

Shukla S.K, Sorayan V.P.S (2005), Thermal modeling of solar stills: an experimental validation. Renewable Energy 30: 683-699.

Singh A, GaikwadRai A.K (2013), Effect of inclination angle and water temperature on internal heat transfer coefficients and productivity of single slope solar still: An indoor simulation. International Journal of Scientific Research 2(7): 142-146.

Tanaka H (2009), Experimental study of a basin type solar still with internal and external reflectors in winter. Desalination 249: 130-134.

Tiwari G.N, Dimri V, Chel A (2009), Parametric study of an active and passive solar distillation system: energy and exergy analysis. Desalination 242: 1-18.

Velmurugan V, Gopalakrishnan M, Raghu R, Srithar K (2008), Single basin solar still with fin for enhancing productivity. Energy Conversion and Management 49: 2602-2608. 